\title{
Records of the giant-armadillo Priodontes maximus (Cingulata: Dasypodidae) in the Atlantic Forest: are Minas Gerais and Espírito Santo the last strongholds of the species?
}

\author{
Ana Carolina Srbek-Araujo ${ }^{1,2}$; Leandro M. Scoss ${ }^{3}$; André Hirsch ${ }^{2}$ \& Adriano G. Chiarello ${ }^{2,4}$ \\ 1 Instituto Ambiental Vale. Rodovia BR-101, km 122, Interior, 29901-401 Linhares, Espírito Santo, Brasil. \\ 2 Programa de Pós-Graduação em Zoologia de Vertebrados, Pontifícia Universidade Católica de Minas Gerais. Avenida Dom \\ José Gaspar 500, Coração Eucarístico, 30535-610 Belo Horizonte, Minas Gerais, Brasil. \\ ${ }^{3}$ Instituto Terra Brasilis. Rua Rio Grande do Norte 1560/405, Funcionários, 30130-131 Belo Horizonte, Minas Gerais, Brasil. \\ ${ }^{4}$ Corresponding author. E-mail: bradypus@pucminas.br
}

\begin{abstract}
We report 20 records of Priodontes maximus (Kerr, 1792) collected between 1990 and 2009 in three nature reserves located in forested areas of southeastern Brazil within the Atlantic Forest biome. Seventeen records were collected in Parque Estadual do Rio Doce (PERD), state of Minas Gerais, two in Reserva Biológica de Sooretama and one in Reserva Natural Vale, both located in the state of Espírito Santo. The records were burrows $(n=11)$, photographs from camera-traps $(n=6)$, sightings $(n=2)$ and carcass $(n=1)$. Given the higher number of records, the PERD seems to maintain the largest population among the three study areas. We searched the literature and found no other recent evidence of the species' presence in the Atlantic forest of Brazil. There are few Museum specimens and a general lack of information on the presence of the species in this biome as a whole. These facts suggest that the conservation status of the giant armadillo is extremely critical in the Atlantic Forest.
\end{abstract}

KEY WORDS. Endangered species; extinction; forest fragmentation; Xenarthra.

The giant-armadillo, Priodontes maximus (Kerr, 1792), is the largest living armadillo (Cingulata: Dasypodidae), reaching 40-60 kg of body weight in nature (NOWAK \& PARADISO 1983, MeritT JR 2006). The species occurs in a wide diversity of environments, including wet forests, South-American Savannas ("Cerrado") and seasonally flooded plains ("Pantanal") (Wetzel 1985, Aguiar \& FonseCa 2008). However its exact habitat preferences are still uncertain (MERITT JR 2006). This species is present to the east of the Andes in northwest Venezuela to French Guiana, Colombia, Equator, Peru, Bolivia, North of Argentina, Paraguay and parts of north, center-west, southeast and south of Brazil (Wetzel 1985, Eisenberg \& Redford 1999, Fonseca \& Aguiar 2004, Gardner 2007).

According to Wetzel (1985), apart from a single specimen from Rio Grande do Sul, museum specimens from Brazil are restricted to the states of the north (Acre, Amazônia, Amapá, Pará, Roraima, Rondônia) and Center-west of the country (Mato Grosso, Mato Grosso do Sul and Goiás). According to Gardner (2007) the Rio Grande do Sul specimen is deposited in the collection of the American Museum of Natural History (\#1308) and is from the municipality of Passo Fundo. Wetzel (1985) states that there is a lack of specimens or any other kind of record for Brazil to the east of the states of Pará, Goiás and São Paulo. In a recent inventory, VAZ (2003) corroborates WeTZEL
(1985) indicating that there are 29 specimens deposited in the main Brazilian museums (Museu de Zoologia da Universidade de São Paulo, Museu Nacional da Universidade Federal do Rio de Janeiro and Museu Paraense Emílio Goeldi). The capture localities are known for 19 of these specimens and are restricted to the Amazon (states of Acre, Pará, Amapá, Maranhão and Mato Grosso) and Cerrado or Pantanal (states of Mato Grosso, Mato Grosso do Sul and Goiás). For the remaining 10 specimens the capture locality is unknown. We know, however, that there is one specimen from the municipality of Linhares, state of Espírito Santo, deposited in the Elias Lorenzutti Museum, in Linhares (\#MEL-M035; Lorenzutti \& Almeida 2006). Another specimen was captured in the region of Linhares in early 1800's by the French botanist and explorer Auguste de Saint-Hilaire (SAinT-Hilaire 1974).

Other types of records confirm the current presence of the species in the states of Minas Gerais (region of Cerrado only: Carter \& EnCarnação 1983, Fundação Biodiversitas 2007) and Espírito Santo (Chiarello 1999, Lorenzutti \& Almeida 2006). The species occurred in the past but there are no recent evidence of its presence in the states of São Paulo (Secretaria DE Estado do Meio Ambiente 1998) and Rio de Janeiro (Bergallo et al. 2000). In Bahia there are confirmed evidences only for the Cerrado region of the Parque Nacional Grande Sertão Veredas 
(R.L.A. Freitas, com. pess., Biotrópicos, Instituto de Pesquisa em Vida Silvestre). In conclusion, the only confirmed information of the presence of the species in the Atlantic Forest biome is restricted to the specimens from Passo Fundo (Rio Grande do Sul) and from Linhares (Espírito Santo).

Although widely distributed in South America, the giantarmadillo always seems to occur at low population densities (Aguiar \& Fonseca 2008). Habitat destruction, hunting for subsistence and for the souvenir market, and the capture of live individuals are the main threats (MeritT Jr 2006, AgUiar \& Fonseca 2008). According to Silveira et al. (1999) and Peres et al. (2003) the occurrence of fire in natural areas is also an important threat to the conservation of the species. Internationally, the giantarmadillo is considered as "Vulnerable" by IUCN (IUCN 2007) and is listed in the Appendix I of CITES (CITES 2007). In Brazil, the taxon is listed as "Vulnerable" (Chiarello et al. 2005), but the conservation status is more critical in the southern and southeastern states of the country. According to red lists already available for some states, the giant-armadillo is listed as "Regionally Extinct" in São Paulo (Secretaria de Estado do Meio Ambiente 1998), as "Critically Endangered" in Espírito Santo (Chiarello et al. 2007) and in Rio de Janeiro (Bergallo et al. 2000), and as "Endangered" in Minas Gerais (Fundação BIodiversitas 2007).

Given the paucity of information on the presence of $P$. maximus in the Atlantic Forest, the objective of this paper is to report new records of this taxon obtained in this biome, discussing them in light of its geographic distribution within the Atlantic forest. The records were obtained in three Atlantic forest reserves, one located in Minas Gerais, the State Park of Rio Doce (Parque Estadual do Rio Doce - PERD), and two located in Espírito Santo, the Sooretama Biological Reserve (Reserva Biológica de Sooretama - RBS) and the Vale Nature Reserve (Reserva Natural Vale - RNV).

\section{MATERIAL AND METHODS}

The PERD is one of the largest remnants of the Atlantic Forest in Minas Gerais, with an area of 36,000 ha $\left(42^{\circ} 33^{\prime} \mathrm{W}\right.$ and $19^{\circ} 37^{\prime} \mathrm{S}$ ) and is surrounded by extensive Eucalyptus plantations and pastures. The reserve is located in the east of the state, a region that already lost $90 \%$ of the original forest cover (FonseCA 1985, M.T. FonseCA unpublished data).The park is considered of extreme importance for the biodiversity conservation of the Atlantic Forest (Ministério do Meio Ambiente 2000, Costa et al. 1998, Drummond et al. 2005) due to the high number of endemic and endangered species. The altitude varies from 230 to $515 \mathrm{~m}$; the climate is tropical semi-wet (Aw) with the rainy season in summer and a 4-5 month long dry season during winter. Mean annual precipitation is $1,480 \mathrm{~mm}$ with a water deficit during May-September and mean annual temperature is $21.9^{\circ} \mathrm{C}$ (J.P. GulHuis, unpublished data). The vegetation is classified as a semideciduous forest according to the Brazilian Vegetation Map (IBGE 1993) or as a Submontane semideciduous forest according to the review by Oliveira-Filho \& Fontes (2000). Overall, the for- est has been little-disturbed, presenting a higher number of late secondary tree species than pioneer ones (W.M. SILVA JR. unpublished data). According to STALLINGs et al. (1991), 77 mammal species are present in PERD, 20\% of which are threatened with extinction (Chiarello et al. 2005, Fundação Biodiversitas 2007). This park includes one of the largest populations of the tapir (Tapirus terrestris) in the Atlantic Forest biome (L. Scoss, unpublished data).

The RNV and RBS are located $30 \mathrm{~km}$ to the North of Doce River (approximately $19^{\circ} 06^{\prime}-19^{\circ} 18^{\prime} \mathrm{S}$ and $39^{\circ} 45^{\prime}-40^{\circ} 19^{\prime} \mathrm{W}$ ), in Espírito Santo. The RNV (21,787 ha) and RBS (24,250 ha) form a contiguous forest block that is traversed in the north-south direction by a national highway (BR-101). These two reserves constitute one of the most important forest remnants of Espírito Santo, amounting to $10 \%$ of the remaining native forests in this state (Fundação SOS Mata Atlântica 2005) and one of the largest forest reserves in the Atlantic forest to the north of Rio de Janeiro. Given their biological importance, they were included in the Atlantic Forest Central Corridor, a large regional planning initiative of the Brazilian government (MINISTÉRIO DO Meio Ambiente et al. 2000). The climate is wet tropical (Aw) with a rainy season in summer and a dry season in winter (Jesus \& RoLim 2005). The annual average temperature is $23.3^{\circ} \mathrm{C}$, varying between 14.8 and $34.2^{\circ} \mathrm{C}$ (averages of the minimum and maximum, respectively). Average annual precipitation is 1,202 $\mathrm{mm}$ but there is strong variability between years (data from the weather station located within RNV; Jesus \& RoLIM 2005). The topography is relatively flat, particularly in RNV with altitudes varying between 28 and 65 m (Jesus \& Rolim 2005). The vegetation is classified as rain forest (floresta ombrófila densa) according to the Vegetation map of Brazil (IBGE 1993) or as lowland rainforest (Oliveira-Filho \& Fontes 2000). However, Jesus \& RoLim (2005) state this forest represents an intermediate typology between the rain forest and the seasonally semideciduous forest since it presents a certain degree of deciduity. Pasturelands and to a lesser degree coffee, papaya and Eucalyptus surround the reserves (Jesus \& Rolim 2005). The mammal fauna is very rich (ChiARello 1999), maintaining important populations of several endangered species (CHIARELlo 2000a). The hunting pressure was more intense in RBS than RNV in the past but since 1998 both areas have been subjected to the same surveillance system, which can be considered one of the most efficient in the Atlantic Forest reserves of Brazil (Chiarello 2000b). The surveillance system was introduced in RNV in 1978.

The data were obtained opportunistically from 1990 to the present and also via camera trapping between 2004 and 2006 (PERD) and between 2005 and 2007 (RNV). The records were classified according to the type of evidence as burrows (fresh and old), visual observations of wild individuals, camera trap (pictures taken automatically by camera traps) and carcasses. The entrance of the $P$. maximus burrow is typically $\geqslant 30$ $\mathrm{cm}$ in height and width (Fig. 1), far larger than the burrows of all other armadillos (CARTER \& ENCARNAÇÃo 1983) and therefore 


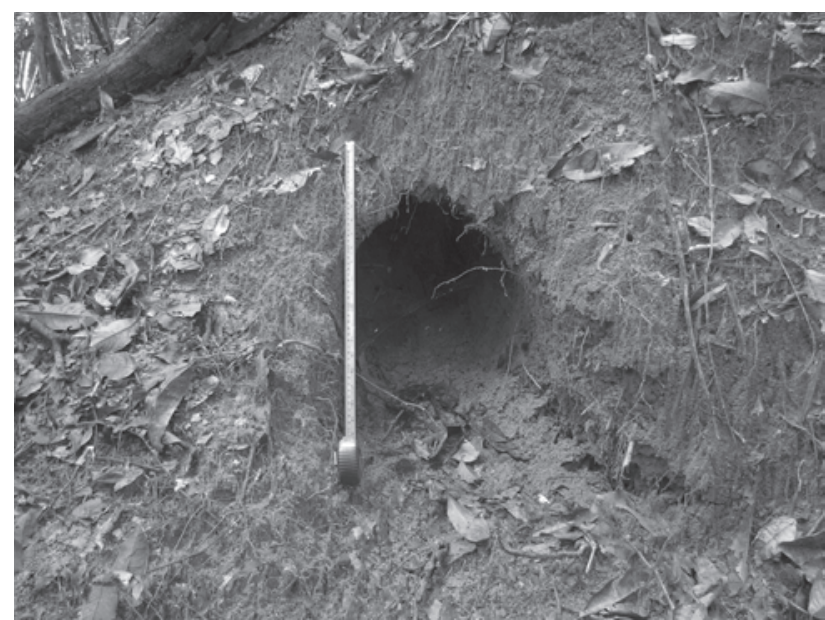

Figure 1. A typical burrow of P. maximus found in Parque Estadual do Rio Doce. The measuring tape is extended to $0.5 \mathrm{~m}$.

they are easily distinguished in the field. In the next two paragraphs, camera trapping details are provided for each reserve separately.

PERD: the camera trapping was carried out in 16 locations spaced $1.5 \mathrm{~km}$ from each other and covered an area of 7,000 ha (SANDERSON \& SUNQUIST 2005). Sampling took place along 120 consecutive days per year, with 60 days during the rainy season and equal sampling effort during the dry season. The camera traps were installed $50 \mathrm{~cm}$ above the ground and were set to operate both day and night with a minimum interval of 90 second between pictures. Every 30 days the cameras were checked and film and batteries were changed (SANDERSON 2002, SANDERSON \& SuNQUisT 2005). In 2004 camera traps of the model CamTrakker ${ }^{\circledR}$ ( $n=16$ ) were used and in 2005 and 2006 those were gradually substituted by units made in Brazil (TrapaCâmera ${ }^{\circledR}$ and Tigrinus ${ }^{\circledR}$ ). Total sampling effort was 4,200 camera trap-nights.

RNV and RBS: between June 2005 and June 2006, camera trapping was carried out in 30 points within three subareas of RNV, each comprised by 10 points spaced a minimum of $2 \mathrm{~km}$ apart from each other. Each subarea was trapped during four months equally distributed between dry and wet seasons. Ten additional points widely scattered throughout RNV were sampled between June 2006 and August 2007. In RBS the camera trapping took place in just two points between June 2006 and August 2007. Sampling effort was 6,500 camera trap-nights in RNV (3,032 camera trap-nights in the first year and 3,468 in the second), and 414 camera trap-nights in RBS, resulting in 6,914 camera trap-nights for RNV+RBS. The cameras were installed $30 \mathrm{~cm}$ above the ground and operated 24 hours/day with an interval of 20 seconds between consecutive pictures. Maintenance was done once every 30 days. During the first year of sampling in RNV and in RBS CamTrakker ${ }^{\circledR}$ units were used ( $\mathrm{n}=20$ and 2 , respectively). In the second year, Tigrinus ${ }^{\circledR}$ cameras $(n=10)$ were used.
For each study area, the sampling success was calculated dividing the number of pictures of the giant-armadillo by the corresponding sampling effort (number of camera traps $\mathrm{x}$ number of days) and expressing the result by 100 camera trap-nights.

\section{RESULTS}

Twenty records of the giant-armadillo were collected since 1990 in the study sites, 17 from PERD (two camera trap records were obtained in the same point "\#11", in Tab. I), two from RBS and one from RNV (Tab. I and Fig. 2). Eleven records were burrows, six were pictures from camera traps, two were direct sightings of live individuals and one was a carcass. Most records $(\mathrm{n}=17)$ were found in or near trails, and three from dirt roads (Figs 3-8).

The 17 records in PERD were widely distributed, indicating that the giant armadillo is present in all areas of this reserve (Fig. 2). The concentration of records in the southern part of this reserve is probably an artifact of sampling as this part was more intensively searched. The camera trap pictures $(n=5)$ were taken between 22:00 and 03:30 h. Given the position of the animals and quality of the pictures, the sex of the photographed individuals could not be identified. Sampling success for PERD was 0.12 pictures/100 camera trap-nights. Two visual records were obtained: one individual was seen crossing a road near the park entrance and another one was sighted by L.G. Dias during a primate line transect sampling (records \# 6 and 10, respectively, Fig. 2 and Tab. I). The latter was the sole visual record of the giant armadillo after more than $600 \mathrm{~km}$ of line transect sampling in this reserve. All burrows were found opportunistically on or near trails and on the edge of dirt roads (see Tab. I and Fig. 2).

Only one record was obtained from camera traps in RBS (a picture taken at 02:56 h; Fig. 5), resulting in a sampling success of 0.242 pictures $/ 100$ camera trap-nights or 0.014 pictures/ camera trap-nights if the effort carried out in both RBS and RNV are pooled. The carcass of an adult individual comprises the second record in RBS. Given the advanced stage of decomposition, it was not possible to identify neither the sex nor the cause of death (Figs 3-4). There was, however, no sign of injuries, lacerations or perforations (part of the skeleton was kept in RNV). This carcass was found near the border of RBS with other privately owned areas and about $2 \mathrm{~km}$ away from the nearest border of RNV (Fig. 2). These two records are $15 \mathrm{~km}$ away one from another, both to the east (picture) and west (carcass) of the highway BR-101 highway, indicating that the species is present in different parts of RBS.

An old burrow found in 1990 is the only record of the species collected thus far in RNV (Fig. 2). As the camera trapping was extensive and covered practically all areas of this reserve, the scarcity of records suggest that the giant armadillo is much rarer there than in the adjacent RBS. Nevertheless as the location where the above-mentioned carcass was found has forests that are contiguous with RNV, the giant armadillo might still be present, at least in parts of RNV.

ZOOLOGIA 26 (3): 461-468, September, 2009 

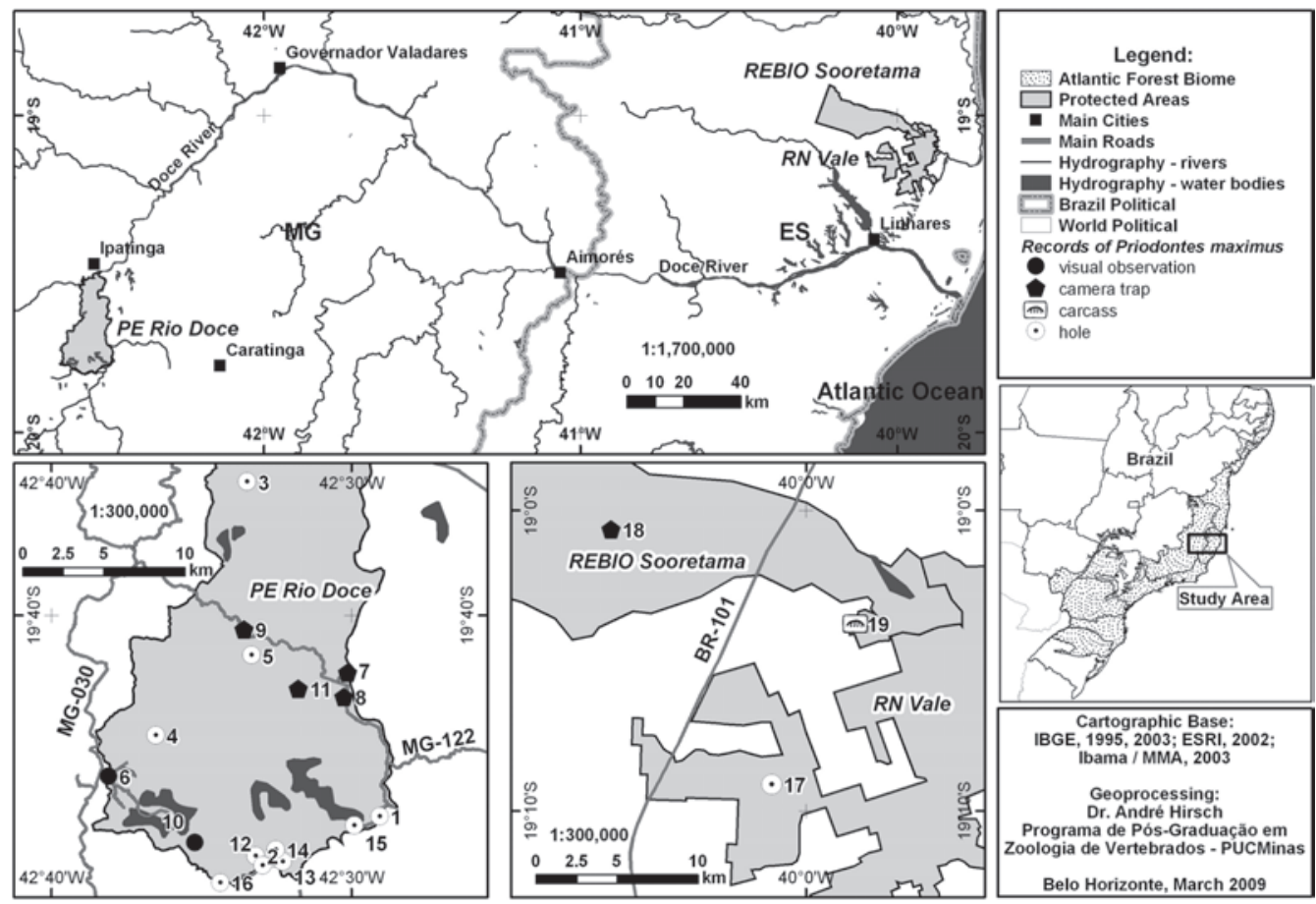

Figure 2. Records location of P. maximus in Parque Estadual do Rio Doce (PERD), Reserva Natural Vale (RNV) and Reserva Biológica de Sooretama (RBS) in southeastern Brazil.

Table I. Records of $P$. maximus in Atlantic forest reserves of Minas Gerais (PERD) and Espírito Santo (RNV and RBS). Record locations (\#) as in figure 1. (PERD) Parque Estadual do Rio Doce, (RNV) Reserva Natural Vale, (RBS) Reserva Biológica de Sooretama.

\begin{tabular}{|c|c|c|c|c|c|c|}
\hline \# & Reserve & Date & Record type & Habitat & Altitude (m) & Observer \\
\hline 1 & PERD & Aug/1992 & burrow & trail & 297 & A. Hirsch \\
\hline 2 & PERD & Apr/2000 & burrow & trail & 275 & L.M.Scoss \\
\hline 3 & PERD & Aug/2001 & burrow & trail & 268 & L.M.Scoss \\
\hline 4 & PERD & Nov/2001 & burrow & trail & 288 & L.M.Scoss \\
\hline 5 & PERD & $\operatorname{Jan} / 2005$ & burrow & trail & 304 & L.M.Scoss \\
\hline 6 & PERD & May/2005 & sighting & dirt road & 292 & L.M.Scoss \\
\hline 7 & PERD & Jun/2005 & camera trap & trail & 269 & L.M.Scoss \\
\hline 8 & PERD & Jun/2005 & camera trap & trail & 287 & L.M.Scoss \\
\hline 9 & PERD & Jun/2005 & camera trap & trail & 305 & L.M.Scoss \\
\hline 10 & PERD & Jun/2006 & sighting & trail & 281 & L.G.Dias \\
\hline 11 & PERD & Jun/2006 & camera trap & trail & 273 & L.M.Scoss \\
\hline 12 & PERD & Feb/2009 & burrow & trail & 354 & A.G Chiarello/A. Hirsch \\
\hline 13 & PERD & $\mathrm{Feb} / 2009$ & burrow & trail & 253 & A.G Chiarello/A. Hirsch \\
\hline 14 & PERD & Feb/2009 & burrow & trail & 316 & A.G Chiarello/A. Hirsch \\
\hline 15 & PERD & $\mathrm{Feb} / 2009$ & burrow & trail & 233 & A.G Chiarello/A. Hirsch \\
\hline 16 & PERD & Feb/2009 & burrow & dirt road & 269 & A.G Chiarello/A. Hirsch \\
\hline 17 & RNV & Jul/1990 & burrow & trail & 55 & A.G.Chiarello \\
\hline 18 & RBS & Aug/2006 & camera trap & dirt road & 65 & A.C.Srbek-Araujo \\
\hline 19 & RBS & Sep/2006 & carcass & trail & 48 & A.C.Srbek-Araujo \\
\hline
\end{tabular}



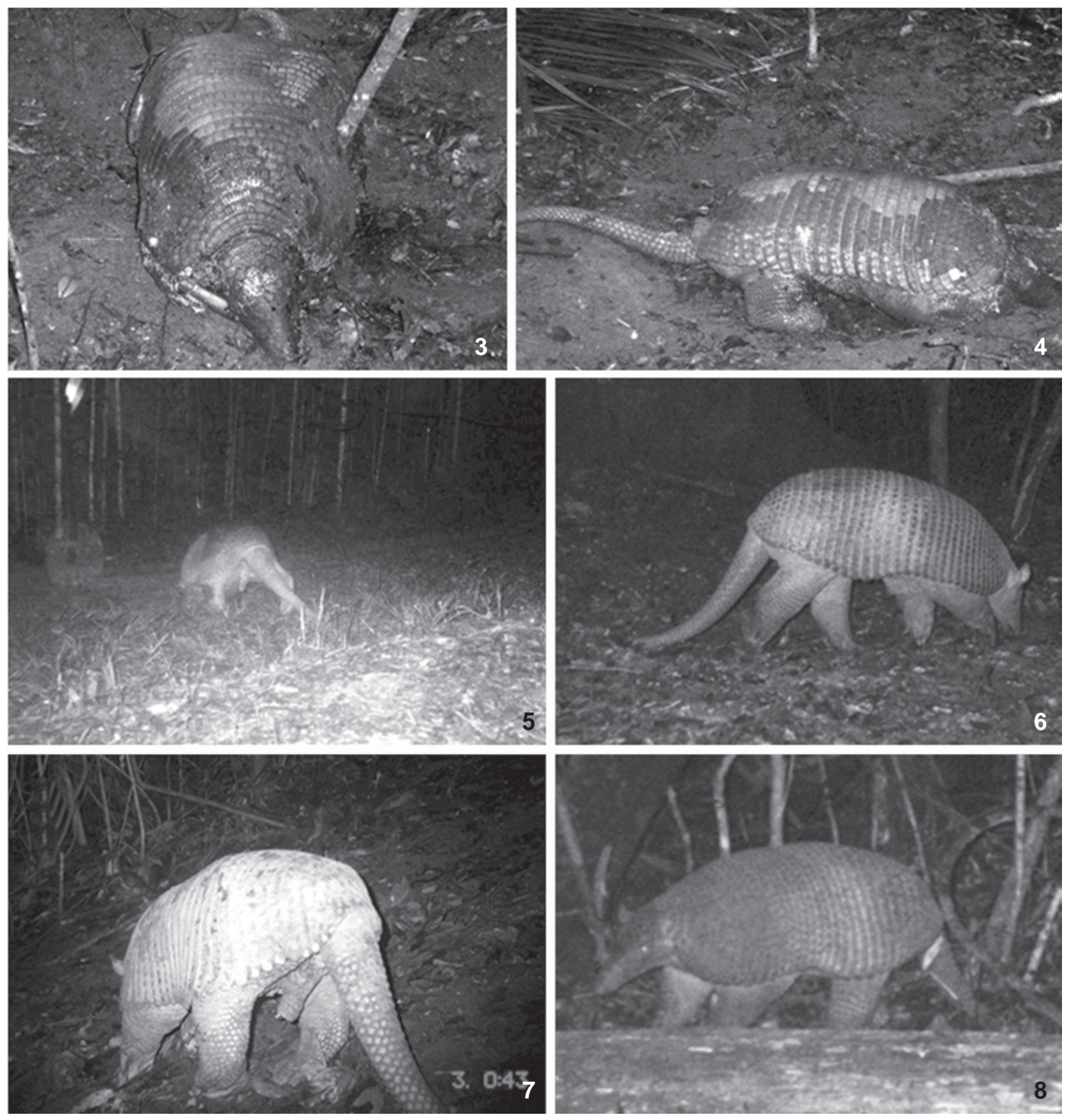

Figures 3-8. Some records of $P$. maximus obtained in Reserva Biológica de Sooretama (3-5) and in Parque Estadual do Rio Doce (6-8). (34) Carcass, (5-8) camera-trap records. See text for details.

\section{DISCUSSION}

The giant armadillo has been recently recorded in the Amazon (Peres 2001, Peres et al. 2003, Trolle 2003a, Martins et al. 2007), Cerrado (Anacleto \& Marinho-Filho 2001, Santos-Filho \& Silva 2001, Marinho-Filho et al. 2002, Rocha \& Dalponte 2006, Anacleto 2007) and Pantanal (Trolle 2003b, Trolle \& Kéry 2005), but such records are exceedingly rare in the Atlantic Forest.
Chiarello et al. (2007) speculated that this species was naturally rare in Espírito Santo. Apart from RBS and RNV, the presence of this armadillo was observed in Floresta Nacional do Rio Preto (municipality of Pedro Canário, north of the state), where an old burrow was found in 1994 (Chiarello et al. 2007). Later information provided by local staff suggests, however, that this species has gone extinct there. In the Atlantic Forest region of Minas Gerais, in addition to the records in PERD, the 
species was recorded in March 2003 in Fazenda Serra Azul, municipality of Bandeira, close to the border with Bahia (Ministério do Meio Ambiente 2006). Six biologically-relevant areas located in the Jequitinhonha and Mucuri Valleys, northern Minas Gerais, were sampled and several interviews were carried out, but apart from this old burrow no other evidence of the presence of the species was detected (MinistérIo Do MeIO Ambiente 2006). As the region has no nature reserve and hunting is rampant, though forbidden by Brazilian law, the probability of a surviving population is nil. Similarly, for southern Bahia, Moura (2003) failed to confirm the presence of the species in 21 fragments sampled in a vast region encompassed between the Contas and Mucuri Rivers.

We failed to find any evidence of the presence of the species in the Atlantic Forest region of São Paulo and Rio de Janeiro. For southern Brazil, there are doubts about its presence in the states of Paraná (Instituto Ambiental do Paraná 2007) and Santa Catarina. In Rio Grande do Sul, there is the single record from Passo Fundo mentioned above (WeTzel 1985). Nevertheless given that the giant armadillo is not even mentioned in the red list of this state (MARQues et al. 2002) it is very likely that the taxon is locally extinct.

Overall, the scarcity of historical and recent records suggests that the giant-armadillo was never abundant in the Atlantic Forest. The fact that most of its geographic distribution is located in the Cerrado and in the Amazon supports this hypothesis (WeTZel 1985, Gardner 2007). On the other hand, one must take into consideration that exhaustive mammal inventories have not being carried out in the greater part of the Atlantic forest remnants. Although the giant armadillo leaves conspicuous burrows and footprints, the species might pass undetected even during mammal surveys. As an example, the mammal inventories carried out in PERD since 2001 (STALLINGS et al. 1991, M.T. FonsECA unpublished data) were not enough to confirm the occurrence of this species in this park. Similarly, about $80 \mathrm{~km}$ of line transect sampling carried out in RBS between 1994 and 1995 failed to provide direct evidence of the species presence there, which was confirmed only by interviews with local staff and people (CHIARELLo 1999). It is likely therefore that some hitherto unknown populations might exist in some unexplored and large fragments of the Atlantic forest. But until this possibility becomes reality, the records in PERD, RNV and RBS constitute the sole evidence of remaining populations of the species in this biome. The importance of these areas for the conservation of the species in eastern Brazil is thus of uttermost importance.

Noss et al. (2004) estimated the relative abundance of $P$. maximus in forested areas of Bolivia from 33 photographic records collected during an effort of 17,000 camera trap-nights. This resulted in a sampling success of 0.19 pictures/100 camera-trap nights, which is similar to that obtained in PERD. Since the giant armadillo range widely and has large home ranges $(>700$ ha; C.D. Encarnação, unpublished dissertation) a few individu- als might have dug the burrows or been captured by the cameras. Nevertheless, the ease with which burrows are found and the widespread distribution of records in PERD indicate that this reserve probably maintains the largest population of the giant armadillo among the three study sites. We suggest that a similar study be repeated in RBS, since up to the moment this reserve has not been inventoried systematically and extensively by camera trapping. On the other hand, the RNV seems to hold a muchreduced population, because two years of intensive use of camera traps failed to record the giant armadillo in this reserve.

Given the large extension of the study areas and difficulty of access to some internal portions, particularly in PERD and in RBS, the action of hunters is present, even in RNV, which has one of the best surveillance systems among the Atlantic forest reserves (CHIAREllo 2000a,b). It is, therefore, imperative to hamper the impact of the illegal hunting on the species, which is perhaps the most immediate threat facing the conservation of the giant anteater in the region. The national highway BR-101 crosses a portion of $5 \mathrm{~km}$ of the RBS and has a continuous and intense traffic of cars and trucks. Although there are traffic signs alerting about the presence of wild animals, drivers routinely ignore these signs and circulate through this part of the road with speeds well above the recommended limits (pers. obs.), causing fatalities of several species of vertebrate, including mammals (S. Rolim, unpublished data). It is plausible, therefore, that the direct and indirect impacts of this road might cause the isolation of populations located to the west and east of it. However, these and other aspects of the natural history of the species, such as diet and habitat preferences, must be investigated before one can accurately assess the size and viability of these populations.

More broadly speaking, we also need initiatives that uncover the existence of surviving populations in other areas of the Atlantic Forest. Based on historic and recent records, some regions such as southern Bahia, eastern and northeastern Minas Gerais and northern Rio de Janeiro should be considered among those with the highest priorities for surveys and inventories. Lastly, studies aiming at determining the degree of genetic diversity, isolation and divergence of the Atlantic Forest populations from those of other biomes are equally important for planning recovery strategies such as translocations and reintroductions that might be necessary in the future.

\section{ACKNOWLEDGEMENTS}

We thank Vale, Instituto Ambiental Vale, Conservação Internacional, TEAM network, Instituto Estadual de Florestas-MG and FAPEMIG (grant number CRA-APQ-5009-5.03/07) for logistic and financial support. We are particularly indebted to R. M. Jesus for his support in RNV. A. Hartuique (Neneco), from the Instituto Ambiental Vale, provided important information regarding RBS. J.G. Sanderson, A.V. Nunes, F.F. Keesen and E. Dutra helped during data collection in PERD. A.G. Chiarello has a research Grant from CNPq (research productivity grant \# 301100/2005-5). 


\section{LITERATURE CITED}

Aguiar, J.M. \& G.A.B. Fonseca. 2008 Conservation status of the Xenarthra, p. 215-281. In: S.F. Vizcaíno \& W.J. Loughry (Eds). The Biology of the Xenarthra. Gainesville, University Press of Florida, 370p.

Anacleto, T.C.S. 2007. Food Habits of Four Armadillo Species in the Cerrado Area, Mato Grosso, Brazil. Zoological Studies 46 (4): 529-537.

Anacleto, T.C.S. \& J.S. Marinho-Filho. 2001. Hábito alimentar do tatu-canastra (Xenarthra, Dasypodidae) em uma área de cerrado do Brasil Central. Revista Brasileira de Zoologia 18 (3): 681-688.

Bergallo, H. de G.; L. Geise; C.R. Bonvicino; R. Cerqueira; P.S. Dándrea; C.E. Esberárd; F.A.S. Fernandez; C.E. Grelle; A. Perachi; S. Siciliano \& S.M. Vaz. 2000. Mamíferos, p. 125135. In: H. De G. Bergallo; C.F.D. Rocha; M.A.S. Alves; Sluys, M.V. (Eds). A Fauna Ameaçada de Extinção do Estado do Rio de Janeiro. Rio de Janeiro, Editora da Universidade Estadual do Rio de Janeiro, 166p.

Carter, T. S. \& C. Encarnação. 1983. Characteristics and use of burrows by four species of armadillos in Brazil. Journal of Mammalogy 64 (1): 103-108.

Chiarello, A.G. 1999. Effects of fragmentation of the Atlantic forest on mammal communities in south-eastern Brazil. Biological Conservation 89: 71-82.

Chiarello, A.G. 2000a. Density and population size of mammals in remnants of Brazilian Atlantic forest. Conservation Biology 14 (6): 1649-1657.

Chiarello, A.G. 2000b. Influência da caça ilegal sobre mamíferos e aves das matas de tabuleiro do norte do Espírito Santo. Boletim do Museu de Biologia Professor Mello Leitão 1112: 229-247.

Chiarello, A.G.; A.B. Rylands; F.H.G. Rodrigues; L.M. de S. Aguiar; R. Cerqueira; T.G. de Oliveira \& V.M. da Silva. 2005. Lista dos Mamíferos ameaçados de extinção no Brasil, p. 27-35. In: A.B.M. Machado; C.S. Martins \& G.M. Drummond (Eds). Lista da Fauna Brasileira Ameaçada de Extinção. Belo Horizonte, Fundação Biodiversitas, 157p.

Chiarello, A.G.; L.P. Costa; Y.L.R Leite; M. Passamani; S. Siciliano \& M. ZorTéa. 2007. Os mamíferos ameaçados de extinção no Estado do Espírito Santo, p. 29-45. In: M. Passamani \& S.L. Mendes (Eds). Espécies da Fauna Ameaçadas de Extinção no Estado do Espírito Santo. Vitória, Instituto de Pesquisas da Mata Atlântica, 140p.

CITES. 2007. Convention on International Trade in Endangered Species of Wild Fauna and Flora. Availabe online at: http:/ /www.cites.org/index.html [Accessed: 19/X/2007]

Costa, C. M. R.; G. Herrmann; C.S. Martins; L.V. Lins \& I.R. Lamas. 1998. Biodiversidade em Minas Gerais: um Atlas para sua conservação. Belo Horizonte, Fundação Biodiversitas, 94p.

Drummond, G. M.; C.S. Martins; A. B. M. Machado; F.A. Sebaio \& Y. Antonini. 2005. Biodiversidade em Minas Gerais: um
Atlas para sua conservação. Belo Horizonte, Fundação Biodiversitas, $2^{\text {nd }}, 222 \mathrm{p}$.

EISENBERG, J.F. \& K.H. REDFORD. 1999. Mammals of the Neotropics. the Central Neotropics: Ecuador, Peru, Bolivia and Brazil. Chicago, University of Chicago Press, vol. 3, 609p.

FonsecA, G.A.B. 1985. The vanishing Brazilian Atlantic Forest. Biological Conservation 34 (1): 17-34.

Fonseca, G.A.B. \& J.M. Aguiar. 2004. The 2004 Edentate species assessment workshop. Edentata 6: 1-26.

FundAÇÃo BIODIVERSITAS. 2007. Revisão das listas das espécies da Flora e da Fauna Ameaçadas de Extinção do Estado de Minas Gerais (Resultados: Lista Vermelha da Fauna de Minas Gerais). Available online at: http://www.biodiversitas.org.br/ listas-mg/RelatorioListasmg_Vol3.pdf [Accessed:5/XII/2007]

Fundação SOS Mata Atlântica. 2005. Atlas dos Remanescentes Florestais da Mata Atlântica/Período 2000-2005. Resultados Quantitativos - Estado do Espírito Santo. São Paulo, Fundação SOS Mata Atlântica, Instituto Nacional de Pesquisas Espaciais, 4p.

GaRdNER, A.L. 2007. Mammals of South America, Marsupials, Xenarthrans, Shrews and Bats. Chicago, The University of Chicago Press, vol. 1, 66p.

IBge. 1993. Mapa de Vegetação do Brasil. Rio de Janeiro, Fundação Instituto Brasileiro de Geografia e Estatística, 1p.

Instituto Ambiental do Paraná. 2007. Livro Vermelho da Fauna Ameaçada do Paraná. Available online at http:// celepar7.pr.gov.br/livrovermelho/index.asp [Accessed: 5/XII/ 2007]

IUCN. 2007. 2007 IUCN Red List of Threatened Species. Available online at: http//www.iucnredlist.org [Accessed: 19/ $\mathrm{X} / 2007]$

Jesus, R.M. \& S.G. Rolim. 2005. Fitossociologia da Mata Atlântica de Tabuleiro. Boletim Técnico da Sociedade de Investigações Florestais 19: 1-149.

Lorenzutti, R. \& A. DE P. Almeida. 2006. A coleção de mamíferos do Museu Elias Lorenzutti em Linhares, Estado do Espírito Santo, Brasil. Boletim do Museu de Biologia Mello Leitão 19: 59-74.

Marinho-Filho, J.; F.H.G. Rodrigues \& K.M. Juarez. 2002. The Cerrado mammals: diversity, ecology, and natural history, p. 266-284. In: P.S. Oliveira \& R.J. MARQuis (Eds). The Cerrados of Brazil: ecology and natural history of a neotropical savanna. New York, Columbia University Press, 424p.

Marques, A.A.B.; C.S. Fontana; E. Vélez; G.A. Bencke; M. Schneider \& R.E. ReIs 2002. Lista das Espécies da Fauna Ameaçada de Extinção do Rio Grande do Sul. Available online at: http://www.agirazul.com.br/Especies/fauna.pdf [Accessed:5/ $\mathrm{XII} / 2007]$

Martins, S.S.; J.G. SAnderson \& J.S. Silva-Júnior. 2007. Monitoring mammals in the Caxiuanã National Forest, Brasil - Fist results from the Tropical Ecology, Assessment and Monitoring (TEAM) program. Biodiversity and Conservation 16 (4): 857 870. 
MERITT JR, D.A. 2006. Research questions on the behavior and ecology of the giant armadillo (Priodontes maximus). Edentata 7: 30-33.

MinistéRIo do MeIo Ambiente. 2000. Avaliação e ações prioritárias para a conservação da biodiversidade da Mata Atlântica e Campos Sulinos. Brasília, Ministério do Meio Ambiente, Secretaria de Biodiversidade e Florestas, 40p.

Ministério do Meio Ambiente. 2006. Biodiversidade e Conservação nos Vales dos Rios Jequitinhonha e Mucuri. Brasília, MMA/Centro de Informação e Documentação Luis Eduardo Magalhães, 243p.

MOURA, R.T. 2003. Distribuição e ocorrência de mamíferos na Mata Atlântica do sul da Bahia. Corredor de Biodiversidade da Mata Atlântica do sul da Bahia. Ilhéus, IESB/CI do Brasil/CABS/UFMG/UNICAMP. Available in CD ROM.

Noss, A.J.; R. PeÑa \& D.I. Rumiz. 2004. Camera trapping Priodontes maximus in the dry forests of Santa Cruz, Bolivia. Endangered Species Update 21: 43-52.

NowaK, R.M. \& J.L. PARADISO. 1983. Walker's Mammals of the World. Baltimore, The Johns Hopkins University Press, $4^{\text {th }}$ ed., 1362p.

Oliveira-Filho, A.T. \& M.A.L. Fontes. 2000. Patterns of floristic differentiation among Atlantic forests in southeastern Brazil and the influence of climate. Biotropica 32 (4b): 793-810.

Peres, C.A. 2001. Synergistic effects of subsistence hunting and habitat fragmentation on Amazonian forest vertebrates. Conservation Biology 15: 1490-1505.

Peres, C.A.; J. Barlow \& T. Haugaasen. 2003. Vertebrate responses to surface fires in Amazonian forests. Oryx 37: 97-109.

Rocha, E.C. \& J.C. Dalponte. 2006. Composição e caracterização da fauna de mamíferos de médio e grande porte em uma pequena reserva de cerrado em Mato Grosso, Brasil. Revista Árvore 30 (4): 669-678.

Saint-Hilaire, A. 1974. Viagem ao Espírito Santo e Rio de Janeiro. Belo Horizonte, Editora da Universidade de São Paulo, Livraria Itatiaia, 121p.

SAnderson, J.G. 2002. Camera Trapping Protocol. Washing- ton, Tropical Ecology, Assessment and Monitoring (TEAM) Initiative. Conservation International, 8p.

SANDERSON, J.G. \& M. Sunquist. 2005. Monitoring medium and large terrestrial mammals: tropical ecology, assessment and monitoring (TEAM) protocols. Washington, Center for Applied Biodiversity Science, Conservation International, 11p.

Santos-Filho, M. \& M.N.F. Silva. 2001. Uso de habitats por mamíferos em área de Cerrado do Brasil Central: um estudo com armadilhas fotográficas. Revista Brasileira de Zoociências 4 (1): 57-73.

Secretaria de Estado do Meio Ambiente. 1998. Fauna Ameaçada no Estado de São Paulo. São Paulo, Secretaria do Meio Ambiente, 56p.

Silveira, L.; F.H.G. Rodrigues; A.T.A. Jácomo \& J.A.F. Diniz Filho. 1999. Impact of Wildfires on the Megafauna of Emas National Park, Central Brazil. Oryx 33 (2): 108-115.

Stallings, J.R.; G.A.B. Fonseca; L.P.S. Pinto; L.M.S. Aguiar \& E.L. Sábato. 1991. Mamíferos do Parque Estadual do Rio Doce, Minas Gerais, Brasil. Revista Brasileira de Zoologia 7 (4): 663-677.

Trolle, M. 2003a. Mammal survey in the Rio Jauaperí region, Rio Negro Basin,the Amazon, Brazil. Mammalia 67 (1): $75-$ 83.

Trolle, M. 2003b. Mammal survey in the southeastern Pantanal, Brazil. Biodiversity and Conservation 12: 823-836.

Trolle, M. \& M. Kéry. 2005. Camera-trap study of ocelot and other secretive mammals in the northern Pantanal. Mammalia 69 (3-4): 405-412.

VAz, S.M. 2003. Lista de localidades de captura de Xenarthros sob ameaça de Extinção no Brasil. Edentata 5: 4-5.

Veloso, P.H.; A.L.R.E. Rangel-Filho \& J.C.A. Lima. 1991. Classificação da vegetação brasileira adaptada a um sistema universal. Rio de Janeiro, IBGE, 123p.

Wetzel, R.M. 1985. Taxonomy and distribution of armadillos, Dasypodidae, p. 23-47. In: G.G. Montgomery (Ed.). The Evolution and ecology of armadillos, sloths and vermilinguas. Washington, Smithsonian Institution Press, 462p.

Submitted: 26.XI.2008; Accepted: 08.IX.2009.

Editorial responsibility: Paulo Inácio López de Prado 